\title{
PENGARUH NILAI KURS (USD) DAN VOLUME PERDAGANGAN SAHAM TERHADAP HARGA SAHAM PADA PERUSAHAAN BANK BUMN YANG GO PUBLIC DI BURSA EFEK INDONESIA \\ TAHUN 2010 s/d 2014
}

\author{
AZNEDRA \\ Dosen Tetap Prodi Akuntansi Fakultas Ekonomi Universitas Riau Kepulauan
}

\begin{abstract}
From the year 2010 until 2014, the domestic currency (rupiah) declined against the US dollar is unstable, affecting the company's stock price at the state-owned banks to go public on the stock exchange Indonesia.

This study was conducted to determine the effect of exchange rate value (USD) and the volume of shares trading on the stock price on the company's state-owned banks to go public on the stock exchanges in Indonesia empirical study period $2010 \mathrm{~s} / \mathrm{d} 2014$. This study uses data sequence (time series ) for a period of 5 years and the sample used is enterprise state-owned banks to go public on the Indonesian stock exchange that consists of only four banks, namely Bank Mandiri (BMRI), BRI (BBRI), BNI (BBNI), and BTN (BBTN). Sampling method used is purposive sampling method, while analysis in this research is descriptive analysis, the classical assumption test, multiple linear regression, $t$-test, $\mathrm{f}$, and the coefficient of determination.

The results obtained in this study is a test on the value of exchange rates (USD) has sig $<a$, that is $0.000<0.05$, which means the value of exchange rates (USD) significantly influence the share price. While the t-test on stock trading volume has sig $>a$, namely $0.552>$ 0.05 , which means the volume of stock trading has no significant effect on the share price. In test F sig 0,000 less than 0.05 , which means that the variable value of exchange rates (USD) and the volume of stock trading is jointly have a significant influence on the share price. Determination coefficient of 0.456 or $45.6 \%$ shows that the percentage contribution of the variable value of exchange rates (USD) and the volume of shares trading on the stock price by $45.6 \%$ while the remaining $54.4 \%$ is influenced by other factors.
\end{abstract}

Keywords: Exchange Rate Value (USD), Stock Trading Volume and Share Price 


\section{LATAR BELAKANG}

Suatu perusahaan untuk menjalankan usahanya membutuhkan modal, baik modal sendiri maupun modal dari luar perusahaan. Modal dari luar perusahaan bagi perusahaan yang go public adalah dengan menjual sahamnya pada pasar modal. Pasar modal merupakan tempat bertemunya orang yang membutuhkan modal dengan orang yang mempunyai modal (investor).

Saham merupakan salah satu instrumen pasar keuangan yang paling populer. Penerbitan saham merupakan salah satu pilihan perusahaan ketika memutuskan untuk pendanaan perusahaan.

Di pasar modal harga saham sehari-hari mengalami fluktuasi baik berupa kenaikan atau penurunan. Saham perbankan merupakan salah satu jenis saham yang banyak menarik para investor untuk berinvestasi. Banyak faktor yang mempengaruhi investor dalam memutuskan pembelian saham perbankan seperti faktor fundamental dari perusahaan dan juga dari faktor-faktor lain diluar faktor fundamental.

Pada tahun 1998 Indonesia mengalami krisis ekonomi dimana nilai tukar rupiah terhadap US dolar sangat rendah hingga mencapai Rp 16.800/US\$ yang berdampak pada perusahaan perbankan. Pada tahun 2015 sampai saat ini nilai tukar rupiah terhadap US dolar kembali mengalami penurunan yang tidak stabil seperti pada Gambar 1.1 yang terdapat dibawah

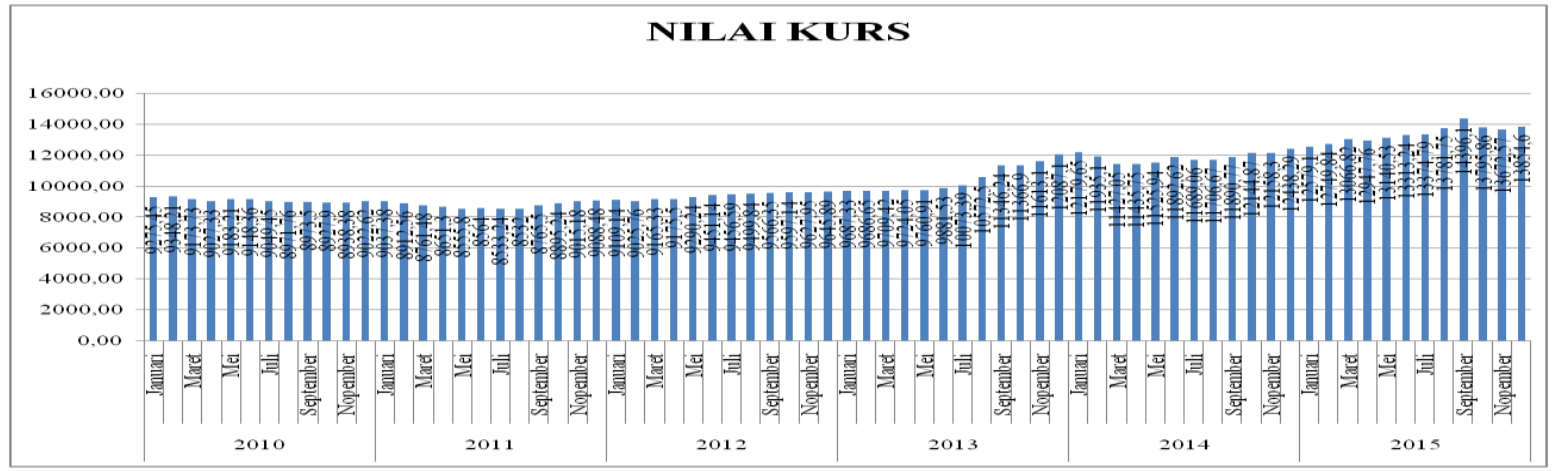

\section{Gambar 1.1 Grafik Nilai Kurs (USD)}

Perusahaan bank BUMN yang go public yaitu BRI (BBRI), Mandiri (BMRI), BNI (BBNI), dan BTN (BBTN). Harga saham perbankan dari ke empat bank ini semuanya mengalami fluktuasi dari tahun ke tahun, kenaikan harga sahamnya tidak konsisten. Dari rata-rata harga saham bank BUMN yang go public, bank BRI memiliki harga saham yang paling tinggi yaitu sebesar Rp 8.149,58 yang kedua yaitu bank Mandiri sebesar Rp 7.802,08 ketiga bank BNI sebesar Rp 4.055,67 dan yang terendah yaitu bank BTN sebesar Rp $1.351,5$.

Nilai tukar adalah perbandingan antara harga mata uang suatu Negara dengan mata uang Negara lain. Kenaikan nilai tukar mata uang dalam negeri terhadap mata uang asing disebut apresiasi (nilai mata uang dalam negeri meningkat). Penurunan nilai tukar mata uang dalam negeri terhadap mata uang Negara lain disebut depresiasi (nilai mata uang dalam negeri merosot). Dalam penelitian ini mengambil variabel Nilai kurs (USD) karena investor yang berinvestasi saham bukan hanya investor lokal tetapi banyak juga investor asing yang menanamkan modalnya ke dalam negeri sehingga nilai kurs (USD) ikut mempengaruhi perkembangan harga saham.

Volume perdagangan saham adalah merupakan perbandingan jumlah saham perusahaan yang diperdagangkan pada waktu t dengan jumlah saham perusahaan yang 
beredar pada waktu t. Ryan Filbert Wijaya (2014: 81) volume adalah sebuah alat analisis yang paling berbeda dengan alat analisis lainnya, karena hanya satu-satunya alat indikator yang perhitungannya berasal dari harga. Secara mendasar dapat dikembalikan menjadi basik ekonomi mikro dimana berlaku hukum permintaan dan penawaran. Sehingga dapat dirumuskan menjadi: bila volume tinggi maka harga akan naik, bila volume turun makan harga akan turun.

Tujuan penelitian ini adalah untuk mengetahui hubungan antara variabel nilai kurs (USD) dan volume perdagangan saham dengan harga saham pada perusahaan bank BUMN yang go public di bursa efek Indonesia, mengukur seberapa besar pengaruh masing-masing variabel yaitu nilai kurs (USD) dan volume perdagangan saham secara parsial terhadap harga saham perusahan ban BUMN yang go public di bursa efek Indonesia. Dan mengukur seberapa besar pengaruh masing-masing variabel yaitu nilai kurs (USD) dan volume perdagangan saham secara simultan (bersama-sama) terhadap harga saham pada perusahaan bank BUMN yang go public di bursa efek Indonesia.

\section{RUMUSAN MASALAH}

Berdasarkan uraian latar belakang penelitian dan penjelasan diatas, maka peneliti merumuskan masalah penelitian sebagai berikut:

1. Apakah ada pengaruh signifikan secara parsial Nilai kurs (USD) terhadap Harga saham pada perusahaan bank BUMN yang go public di bursa efek Indonesia?

2. Apakah ada pengaruh signifikan secara parsial Volume perdagangan saham terhadap Harga saham pada perusahaan bank BUMN yang go public di bursa efek Indonesia?

3. Apakah ada pengaruh signifikan secara simultan Nilai kurs (USD) dan Volume perdagangan saham terhadap Harga saham pada perusahaan bank BUMN yang go public di bursa efek Indonesia?

\section{TUJUAN PENELITIAN}

Sesuai dengan rumusan permasalahan diatas, maka tujuan utama dari penelitian ini adalah:

1. Untuk mengetahui pengaruh secara parsial antara Nilai kurs (USD) terhadap Harga saham pada perusahaan bank BUMN yang go public di bursa efek Indonesia.

2. Untuk mengetahui pengaruh secara parsial antara Volume perdagangan saham terhadap Harga saham pada perusahaan bank BUMN yang go public di bursa efek Indonesia.

3. Untuk mengetahui pengaruh secara simultan antara Nilai kurs (USD) dan Volume perdagangan saham terhadap Harga saham pada perusahaan bank BUMN yang go public di bursa efek Indonesia.

\section{MAMFAAT PENELITIAN}

1. Hasil penelitian ini dapat dijadikan sebagai bahan kajian dan studi lanjutan yang relevan serta memberikan informasi dan gambaran mengenai Nilai kurs (USD) dan 
Volume perdagangan saham dan pengaruhnya terhadap Harga saham pada perusahaan bank BUMN yang go public.

2. Meningkatkan pemahaman dan pengenalan terhadap permasalahan mengenai Nilai kurs (USD), Volume perdagangan saham serta bagaimana pengaruhnya terhadap Harga saham pada perusahaan bank BUMN yang go public sehingga peneliti bisa menerapkan teori yang didapat selama perkuliahan dengan praktek yang sebenarnya.

\section{TINJAUAN PUSTAKA}

Ikatan Bankir Indonesia (2013: 81) menyatakan nilai tukar (exchange rate) merupakan perbandingan antara unit suatu mata uang dan sejumlah mata uang lainnya dimana unit tersebut bisa ditukar. Nilai tukar atau kurs dapat dijelaskan sebagai sejumlah mata uang asing yang disebut direct quote, atau sejumlah mata uang lokal yang disebut indirect quotes. Misalnya kurs rupiah terhadap US dolar menunjukkan berapa rupiah yang diperlukan untuk ditukarkan dengan satu US dolar.

Volume perdagangan saham merupakan rasio antara jumlah lembar saham yang diperdagangkan pada waktu tertentu terhadap jumlah saham yang beredar pada waktu tertentu (Husnan, 2005).

Harga saham merupakan harga jual beli yang sedang berlaku di pasar efek yang ditentukan oleh kekuatan pasar dalam arti tergantung pada kekuatan permintaan dan penawaran. Kesuma (2009: 40) harga saham adalah nilai nominal penutupan (closing price) dari penyertaan atau pemilikan seseorang atau badan dalam suatu perusahaan atau perseroan terbatas yang berlaku secara regular di pasar modal Indonesia.

Dari variable yang telah disebutkan diatas, penulis menggambarkan kerangka berpikir yang dapat dilihat sebagai berikut ini:

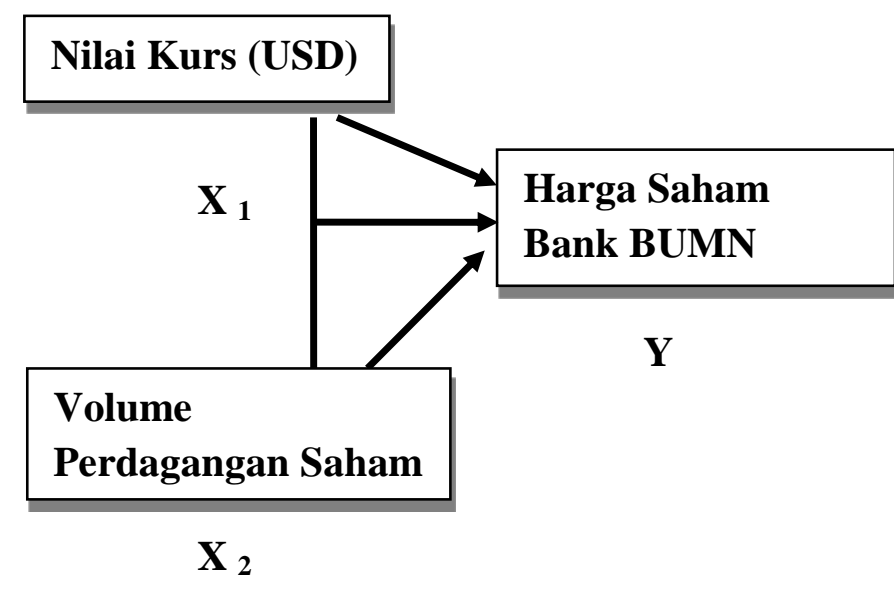

Hipotesis penelitian ini adalah seagai berikut:

1. $\mathrm{H}_{0}$ : Nilai kurs (USD) tidak berpengaruh secara signifikan terhadap Harga saham pada perusahaan bank BUMN yang go public di bursa efek Indonesia.

$\mathrm{H}_{1}$ : Nilai kurs (USD) berpengaruh secara signifikan terhadap Harga saham pada perusahaan bank BUMN yang go public di bursa efek Indonesia.

2. $\mathrm{H}_{0}$ : Volume perdagangan saham tidak berpengaruh secara signifikan terhadap Harga saham pada perusahaan bank BUMN yang go public di bursa efek Indonesia. 
$\mathrm{H}_{1}$ : Volume perdagangan saham berpengaruh secara signifikan terhadap Harga saham pada perusahaan bank BUMN yang go public di bursa efek Indonesia.

3. $\mathrm{H}_{0}$ : Nilai kurs (USD) dan Volume perdagangan saham tidak berpengaruh secara signifikan terhadap Harga saham pada perusahaan bank BUMN yang go public di bursa efek Indonesia.

4. $\mathrm{H}_{1}$ : Nilai kurs (USD) dan Volume perdagangan saham berpengaruh secara signifikan terhadap harga saham pada perusahaan bank BUMN yang go public di bursa efek Indonesia.

\section{A. METODOLOGI PENELITIAN}

\section{Objek Penelitian}

Dalam penelitian ini yang menjadi objek penelitian adalah empat perusahaan perbankan BUMN yang go public di bursa efek Indonesia dimana lokasi penelitian dilakukan pada IDX (Indonesia Stock Exchange) bursa efek Indonesia yang beralamat di komplek Mahkota Raya blok A No. 11 Batam Centre kota Batam.

\section{Jenis Data}

Jenis data yang digunakan dalam penelitian ini adalah data kuantitatif, yaitu data yang diukur dalam suatu skala numerik (angka). Data kuantitatif disini berupa data runtun waktu (time series) yaitu data yang disusun menurut waktu pada suatu variabel tertentu.

Penelitian ini menggunakan data sekunder yaitu data yang telah dikumpulkan oleh lembaga pengumpul data, serta dipublikasikan pada masyarakat pengguna data. Data berupa informasi yang didapat dari situs lembaga tertentu seperti www.bi.go.id untuk data nilai kurs tengah (USD), dan www.idx.co.id (IDX Batam) untuk data tentang volume perdagangan saham dan harga saham periode tahun 2010 s/d 2014.

\section{Teknik Pengambilan Sampel}

Dalam penelitian ini teknik pengambilan sampel dengan teknik sampling purposive. Sampel data dalam penelitian ini adalah kalkulator kurs BI tentang Nilai kurs tengah dan laporan tahunan IDX tentang Volume perdagangan saham dan Harga saham pada perusahaan bank BUMN yang go public di bursa efek Indonesia periode tahun 2010 s/d 2014. Sampel pada penelitian ini dapat dilihat

\section{Definisi Operasional Variabel}

Variabel yang akan diteliti oleh penulis ada 3 (tiga) variabel, yaitu 2 (dua) variabel bebas (variabel independen) yaitu nilai kurs (USD), volume perdagangan saham, dan 1 (satu) variabel terikat (variabel dependen) yaitu harga saham.

\section{Teknik Analisis Data}

Teknik analisis data yang digunakan dalam penelitian ini adalah metode statistik deskriptif dan metode statistik inferensial, sebagai berikut:

\section{Uji Kualitas Data}




\section{Uji asumsi klasik}

Uji asumsi klasik regresi yang digunakan di dalam penelitian skripsi ini adalah Uji normalitas, Uji multikolinearitas, Uji heteroskedastisitas, Uji autokorelasi.

Uji normalitas di lakukan guna mengetahui apakah nilai residu (perbedaan yang ada) yang diteliti memiliki distribusi normal atau tidak normal (Agung Edy Wibowo, 2012: 61). Uji multikolinearitas diperlukan untuk mengetahui ada tidaknya variabel independen yang memiliki kemiripan antara variabel independen dalam suatu model (V. Wiratna Sujarweni, 2015: 185). Heteroskedastisitas menguji terjadinya perbedaan variance residual suatu periode pengamatan ke periode pengamatan yang lain (V. Wiratna Sujarweni, 2015: 186). Uji autokorelasi dalam suatu model bertujuan untuk mengetahui ada tidaknya korelasi antara variabel pengganggu pada periode tertentu dengan variabel sebelumnya (V. Wiratna Sujarweni, 2015: 186).

\section{Uji Regresi}

\section{Regresi linier berganda}

Regresi linier berganda yang memiliki satu variabel dependen dan lebih dari satu variabel independen (V. Wiratna Sujarweni, 2015: 149). Model persamaan regresi linier berganda seperti Rumus 3.1 sebagai berikut:

$\mathrm{Y}=\mathrm{a}+\mathrm{b}_{1} \mathrm{X}_{1}+\mathrm{b}_{2} \mathrm{X}_{2}+\ldots . .+\mathrm{e}$

Keterangan :

Y = Harga saham

$\mathrm{X}_{1} \quad=$ Nilai kurs (USD)

$\mathrm{X}_{2} \quad=$ Volume perdagangan

a $\quad=$ Konstanta

$\mathrm{b}_{1}, \mathrm{~b}_{2}=$ Koefisien regresi $\mathrm{X}_{1}, \mathrm{X}_{2}$

$\mathrm{e} \quad=$ Error

\section{Uji t (parsial)}

Menurut Priyanto (2010: 68) uji ini digunakan untuk mengetahui apakah dalam model regresi variabel independen (X) secara parsial berpengaruh signifikan terhadap variabel dependen (Y). Rumus thitung pada analisis regresi dapat dilihat pada dibawah ini:

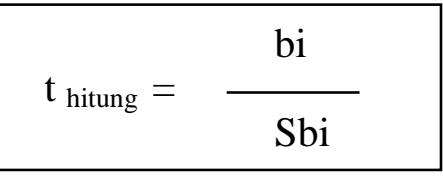


Keterangan:

$\mathrm{Bi}=$ Koefisien regresi variabel $\mathrm{i}$

Sbi $=$ Standar error variabel $\mathrm{i}$

\section{Uji F (simultan)}

Menurut Priyanto (2010: 67) mengungkapkan bahwa uji ini digunakan untuk mengetahui apakah variabel independen $\left(\mathrm{X}_{1}\right.$ dan $\left.\mathrm{X}_{2}\right)$ secara bersama-sama berpengaruh secara signifikan terhadap variabel dependen $(\mathrm{Y}) . \mathrm{F}_{\text {hitung }}$ dapat dicari dengan rumus sebagai berikut:

$$
\begin{aligned}
& F=\frac{R^{2} /(k-1)}{1-R^{2} /(n-k)} \\
& \text { Keterangan! } \\
& \mathrm{R}^{2}=\text { Koefisien Determinasi } \\
& \mathrm{k}=\text { jumlah variabel keseluruhan } \\
& \mathrm{n}=\text { jumlah sampel }
\end{aligned}
$$

\section{Uji koefisien determinasi (adjusted R square)}

Koefisien determinasi atau $\mathrm{R}$ Square $\left(\mathrm{R}^{2}\right)$ digunakan untuk melihat sejauh mana model yang terbentuk dapat menjelaskan kondisi yang sebenarnya (Agung Edy Wibowo, 2012: 121). Sedangkan rumus koefisien determinasi $\left(\mathrm{R}^{2}\right)$ adalah seperti dibawah ini:

$$
\mathrm{R}^{2}=\frac{\text { Sum of Squares Regression }}{\text { Sum Squares Total }}
$$

\section{B. HASIL DAN PEMBAHASAN \\ Uji Kualitas Data Asumsi Klasik}

Berdasarkan uji normalitas histogram kurva membentuk lonceng (bell shaped curve) atau nilai Kolmogorov-Smirnov memiliki tingkat signifikansi $0.983>0,05$ yang menyatakan bahwa data memiliki distribusi normal.

Berdasrkan uji multikoleaniritas didapat nilai tolerance masing-masing variabel seperti nilai kurs (USD) sebesar 1.000 dan volume perdagangan saham sebesar 1.000 masingmasing melebihi nilai tolerance yang ditetapkan yaitu 0,10. Serta nilai VIF masing-masing variabel seperti nilai kurs (USD) sebesar 1.000, volume perdagangan saham sebesar 1.000 tidak melebihi nilai VIF yang ditetapkan yaitu sebesar 10. Hal tersebut dapat diartikan bahwa tidak terdapat multikolinearitas pada penelitian ini.

Pada uji heteroskedastisitas pola gambar Scatterplot menunjukkan tidak ada pola yang jelas serta titik-titik yang menyebar diatas dan dibawah angka nol pada sumbu Y berarti dapat 
disimpulkan tidak terjadi heterokedastisitas. Atau dengan uji Park Gleyser menunjukkan bahwa nilai probabilitas atau nilai signifikansinya masing-masing variabel bernilai $1.000>$ nilai alphanya $(0,05)$ sehingga dapat dipastikan model tersebut tidak mengalami gejala heteroskedastisitas.

Pada uji autokorelasi probabilitas nilai Durbin-Watson adalah 0,501 >0.05, maka dapat dipastikan bahwa model tersebut tidak mengalami gejala autokorelasi.

\section{Uji Regresi}

\section{Uji regresi linier berganda} berikut:

Berdasarkan hasil uji regresi linier berganda maka didapatkan persamaan sebagai

$$
Y=1764,610+2,048 X_{1}+0,000 X_{2}
$$

Artinya:

1. Konstanta $=1764,610$

Konstanta memiliki nilai sebesar 1764,610 ini menunjukkan jika $X_{1}$ (Nilai kurs (USD)) dan $\mathrm{X}_{2}$ (Volume perdagangan saham) nilainya adalah nol, maka $\mathrm{Y}$ (Harga saham) memiliki nilai 1764,610 .

\section{Nilai kurs (USD) $\left(\mathrm{X}_{1}\right)=2,048$}

Variabel $\mathrm{X}_{1}$ (Nilai kurs (USD)) memiliki nilai koefisien sebesar 2,048, ini berarti jika variabel independen lain nilainya tetap atau tidak berubah, maka setiap kenaikan 1 poin atau $1 \%$ variabel $\mathrm{X}_{1}$ (Nilai kurs (USD)) akan meningkatkan nilai Harga saham (Y) sebesar 2,048. Koefisien variabel $X_{1}$ (Nilai kurs (USD)) bernilai positif berarti terdapat hubungan positif antara $\mathrm{X}_{1}$ (nilai kurs (USD)) dengan Y (Harga saham), artinya semakin meningkat nilai $\mathrm{X}_{1}$ (Nilai kurs (USD)) maka akan meningkatkan nilai $\mathrm{Y}$ (Harga saham).

3. Volume perdagangan saham $\left(\mathrm{X}_{2}\right)=0,00$

Variabel $\mathrm{X}_{2}$ (Volume perdagangan saham) memiliki nilai koefisien sebesar 0,000 , ini berarti jika variabel independen lain nilainya tetap atau tidak berubah, maka setiap kenaikan 1 poin atau $1 \% \mathrm{X}_{2}$ (Volume perdagangan saham) tidak mempengaruhi nilai Harga saham (Y) karena mempunyai nilai koefisien sebesar 0,000 artinya semakin meningkat nilai $\mathrm{X}_{2}$ (Volume perdagangan saham) maka tidak meningkatkan nilai Y (Harga saham).

\section{Uji t (parsial)}

Hasil uji t pada nilai kurs (USD) terhadap harga saham menghasilkan nilai koefisien regresi Nilai kurs (USD) memiliki tingkat signifikansi 0.000 , nilai ini lebih kecil dari 0.05 atau sig $<a$, ini berarti hipotesis penelitian yang menyatakan "Nilai kurs (USD) memiliki pengaruh yang signifikan terhadap Harga saham". Dan metode lain dapat digunakan adalah membandingkan nilai $\mathrm{T}_{\text {hitung }}$ dengan $\mathrm{T}_{\text {tabel. }}$ Jika $\mathrm{T}_{\text {hitung }}$ lebih besar dari $\mathrm{T}_{\text {tabel }}$ maka hipotesis $\mathrm{H}_{1}$ diterima, dan sebaliknya. Dari $\mathrm{T}_{\text {hitung }}$ memiliki nilai 6,881 sedangkan $\mathrm{T}_{\text {tabel }}$ memiliki nilai 2,002 ini berarti $\mathrm{T}_{\text {hitung }}>\mathrm{T}_{\text {tabel }}$, sehingga hipotesis penelitian $\mathrm{H}_{1}$ diterima. 
Hasil uji t pada volume perdagangan saham terhadap harga saham menghasilkan nilai koefisien regresi memiliki tingkat signifikansi 0,552, nilai ini lebih besar dari 0.05 atau sig > $a$, ini berarti hipotesis penelitian yang menyatakan "Volume perdagangan saham tidak memiliki pengaruh yang signifikan terhadap Harga saham" sehingga hipotesis penelitian $\mathrm{H}_{0}$ diterima.

\section{Uji F (simultan)}

Hasil uji $\mathrm{F}$ menunjukkan bahwa $\mathrm{F}_{\text {hitung }}=23,877>\mathrm{F}_{\text {tabel }}=3,16$ (lihat pada tabel distribusi F) dan signifikansinya $=0,000<0,05$, maka dapat disimpulan variabel Nilai kurs $\left(\mathrm{X}_{1)}\right.$ dan Volume perdagangan saham $\left(\mathrm{X}_{2}\right)$ secara bersama-sama berpengaruh secara signifikan terhadap variabel Harga saham (Y).

Pada uji koefisien determinasi terlihat angka $\mathrm{R}^{2}$ sebesar 0,456 . Ini berarti persentase sumbangan variabel $\mathrm{X}_{1}$ (Nilai kurs (USD)) dan $\mathrm{X}_{2}$ (Volume perdagangan saham) dalam model regresi sebesar 45,6 \%. Atau variabel Y (Harga saham) dapat dijelaskan oleh variasi variabel $X_{1}$ (Nilai kurs (USD)) dan $X_{2}$ (Volume perdagangan saham) 45,6\%, sedangkan sisanya sebanyak $54,4 \%$ dijelaskan oleh variabel lain yang tidak dimasukkan dalam penelitian ini.

\section{KESIMPULAN DAN SARAN}

\section{Kesimpulan}

Berdasarkan hasil dan pembahasan maka diperoleh kesimpulan sebagai berikut:

1. Uji t untuk variabel nilai kurs mempunyai nilai signifikansi $0.000<0.05$ yang artinya variabel Nilai kurs (USD) berpengaruh signifikan secara parsial terhadap Harga saham pada perusahaan bank BUMN yang go public di bursa efek Indonesia.

2. Uji t untuk variabel volume perdagangan saham mempunyai nilai signifikansi 0,552 > 0.05 yang artinya variabel Volume perdagangan saham tidak berpengaruh signifikan secara parsial terhadap Harga saham pada perusahaan bank BUMN yang go public di bursa efek Indonesia.

3. Hasil uji $F$ diperoleh $F_{\text {hitung }}$ sebesar 23,877 dengan sig. 0.000. Hal ini menunjukkan bahwa sig. 0.000 lebih kecil dari 0.05 maka $\mathrm{H}_{0}$ ditolak, artinya secara simultan variabel Nilai kurs (USD) dan Volume perdagangan saham berpengaruh secara signifikan terhadap Harga saham pada perusahaan bank BUMN yang go public di bursa efek Indonesia.

\section{Keterbatasan}

Keterbatasan dalam penelitian ini adalah:

1. Sampel yang digunakan hanya pada perusahaann bank BUMN yang go public di bursa efek Indonesia

2. Jumlah sampel yang gunakan hanya pada 4 perusahaan bank BUMN yang go public di bursa efek Indonesia

3. Penelitian ini hanya menggunakan 2 variabel independen yang terdiri dari Nilai kurs (USD) dan Volume perdagangan saham yang dianggap dapat mempengaruhi Harga saham pada perusahaan bank BUMN yang go public di bursa efek Indonesia

\section{Saran}


Berdasarkan kesimpulan diatas dari hasil analisis dan pembahasan, maka dapat direkomendasikan beberapa hal sebangai berikut:

1. Dalam penelitian ini bahwa Nilai kurs (USD) berpengaruh secara signifikan terhadap Harga saham, dengan demikian pemerintah harus mengendalikan perekonomian dengan bijak termasuk pengendalian nilai kurs, agar gairah investasi dalam negeri semakin meningkat.

2. Dalam penelitian ini bahwa Volume perdagangan saham tidak berpengaruh signifikan terhadap harga saham karena adanya stock split, dengan demikian para investor harus menganalisa volume perdagangan saham suatu perusahaan sebelum membeli sahamnya.

3. Penelitian selanjutnya, diharapkan dapat dikembangkan dengan memperpanjang periode penelitian dan memperbanyak variabel penelitian.

\section{DAFTAR PUSTAKA}

Agustina dan Fitry Sumartio (2014), "Analisa faktor-faktor yang mempengaruhi pergerakan harga saham pada perusahaan pertambangan”, Medan, STIE Mikroskil

Ath Thobarry, Achmad (2009), "Analisis pengaruh nilai tukar, Suku bunga, laju inflasi, dan pertumbuhan GDP terhadap indeks harga saham sector property (periode tahun 20002008)'. Semarang, Universitas Diponegoro

Azwir dan Achmad (2010), “ Pengaruh Nilai Kurs, Inflasi, Suku Bunga Deposito dan Volume Perdagangan Saham terhadap Return Saham pada perusahaan perbankan yang terdaftar di Bursa Efek Indonesia”, Pekan Baru, Universitas Riau

Cristiani Ginting, Selaras dan Henny Rahyuda (2015), "Perbedaan volume perdagangan saham dan abnormal return sebelum dan sesudah peristiwa stock split pada perusahaan di bursa efek Indonesia", Bali, Universitas Udayana (UNUD)

Darmadi, Harmid (2011), “Metode penelitian pendidikan”, Jakarta, Alpha Beta

Fazri Setiadi, Fakhrizal dkk (2015), "Pengaruh Return On Asset (ROA) dan Return On Equity (ROE) terhadap harga saham”, Bandung, Universitas Islam Bandung

Filbert Wijaya, Ryan S.Sn,ME (2014), "Investasi Saham ala Swing Trader Dunia", Jakarta, PT. Elex Media Komputindo

Ikatan Bankir Indonesia (2013), “Memahami bisnis bank”, Jakarta, PT. Gramedia Pustaka Utama

Jefferson, Jere dan Naning Sudjatmoko (2013), "Shopping Saham Modal Sejuta”, Jakarta, PT. Elex Media Komputindo

Manurung, Adler Haymans (2013), “Berani bermain Saham”, Jakarta, PT. Kompas Media Nusantara

Nugroho, Heru (2008), "Analisis pengaruh inflasi, suku bunga, kurs, dan jumlah uang beredar terhadap indeks LQ45 (periode 2002-2007)”, Semarang, Universitas Diponegoro

Nur Windasari, Alifah (2015), "Analisis pengaruh tingkat inflasi, nilai kurs rupiah, tingkat suku bunga terhadap harga saham di bursa efek Indonesia”, Surakarta, Univesitas Muhammadiyah

Sujarweni, V. Wiratna (2015), “SPSS untuk Penelitian”, Yogyakarta, Pustaka Baru Press

Tribunnews (2014), "Tiga factor yang mempengaruhi pergerakan nilai tukar rupiah", Jakarta, Tribun

Wibowo, Agung Edy SE, M.Si (2012), “Aplikasi praktis SPSS dalam penelitian”, Yogyakarta, Gava media

Woshi Patama, Billy (2014), “Analisis perbedaan harga saham dan volume perdagangan saham sebelum dan sesudah pengumuman dividen pada perusahaan manufaktur yang terdaftar di bursa efek Indonesia", Bengkulu, Universitas Bengkulu

www.bi.go.id 


\section{www.idx.co.id}

Yahya Sarono, Dwi (2014), "Pengaruh inflasi, tingkat suku bunga SBI, dan nilai tukar dolar terhadap harga saham properti yang terdaftar dalam LQ 45 di bursa efek Indonesia periode tahun 2009 - 2012", Surakarta, Universitas Muhammadiyah. 